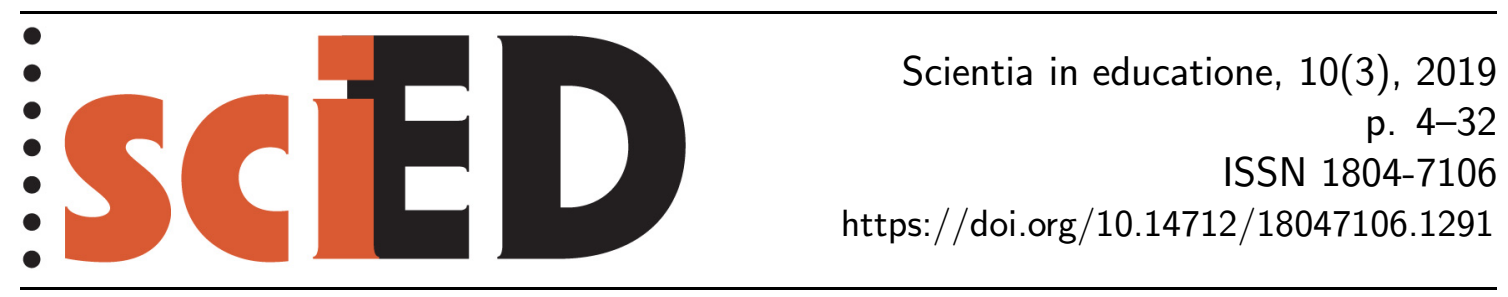

\title{
A Comparison of Lower Secondary School Education of Mathematics in the Czech Republic and Selected Countries with Respect to Curriculum Documents
}

\author{
Vlasta Moravcová, Petra Surynková, Jana Hromadová
}

\begin{abstract}
Results from the PISA international surveys in 2012 and 2015 show that the performance of Czech pupils in mathematics was statistically comparable with the OECD average. However, in the long-term comparison, the results appear to have statistically worsened in the Czech Republic. The PISA score of other European countries with similar economies in terms of GDP and common historical-cultural development, namely Estonia, Poland, and Slovenia, was higher or even significantly higher. The search for the causes of this leads, among other things, to the study of the mathematics curricula of these states. Our paper gives a brief overview of the education systems of the selected countries, while also conducting a qualitative comparative analysis of relevant curriculum documents for lower secondary education. We place emphasis on the differences between the Czech curriculum and the curricula of the other countries. This is explored with the overall aim of formulating educational objectives pertaining to mathematics learning, the subject matter and its division, and required learning outcomes. In the last chapter we present the most significant differences (the lowest number of mathematics lessons, the absence of general mathematical goals and competencies, the lack of emphasis on home preparation of pupils, the absence of unified testing and insufficiently detailed learning content and outcomes), which could be an inspiration for improving the Czech mathematics curriculum.
\end{abstract}

Key words: ISCED 2, curriculum, comparative education, mathematics education.

\section{Porovnání přístupu České republiky a vybraných zemí $\mathrm{k}$ výuce matematiky na úrovni nižšího sekundárního vzdělávání z pohledu kurikulárních dokumentů}

\begin{abstract}
Abstrakt
Ve srovnávacích testech PISA z let 2012 a 2015 výsledky žáků Ceské republiky v testování matematické gramotnosti odpovídaly průměru zemí OECD, v dlouhodobém srovnání se tyto výsledky mírně zhoršují. Jiné evropské státy se srovnatelným HDP a podobným
\end{abstract}


sociálně-kulturním vývojem, konkrétně Estonsko, Slovinsko a Polsko, však dosahují v uvedených letech nepatrně či významně lepších výsledků. Pátrání po přičinách tohoto rozdílu vede mimo jiné ke zkoumání kurikula matematiky těchto států. V příspěvku předkládáme stručný přehled vzdělávacích systémů vybraných zemí a kvalitativní srovnávací analýzu příslušných kurikulárních dokumentů pro nižší sekundární vzdělávání. Důraz je kladen na odlišnosti od kurikula Ceské republiky zejména s ohledem na formulace cílů, řazení a obsah učiva a požadované výstupní úrovně žáků. V poslední kapitole uvádíme nejvýznamnější zjištěné rozdíly (nejnižší počet hodin výuky matematiky, absence obecných matematických cílů a kompetencí, chybějící důraz na domácí přípravu, absence jednotného testování a nedostatečně podrobný obsah a výstupy vzdělávání), které by mohly být inspirací pro zkvalitnění českého kurikula matematiky.

Klíčová slova: ISCED 2, kurikulum, srovnávací pedagogika, vzdělávání matematice.

The contribution compares four countries in the European Union with the common historical-cultural development: the Czech Republic, Estonia, Poland, and Slovenia. The selected countries passed through similar historic events in the $20^{\text {th }}$ century experienced a number of war conflicts, were occupied several times, their borderlines changed many times. The situation stabilized after the Second World War. Afterwards, all four countries fell within the Soviet sphere of influence (Estonia was part of the Soviet Union) and their economies were centrally planned and tightly linked to the Soviet Union. At the turn of the 1980s and 1990s, the economic systems were changed to a market economy and the systems of government became democratic. In consequence of forty-some years of centrally planned economies the selected countries have similar economic problems - they lag further behind the most developed countries in the European Union and the economies recover slowly. These facts are obvious from the National Average Wage and from Gross Domestic Product (GDP), that was $89 \%$ in the Czech Republic, $77 \%$ in Estonia, $70 \%$ in Poland and $85 \%$ in Slovenia in $2017^{1}$ (Eurostat, 2017a, b). Education directly affects economic growth and vice versa.

All four countries joined the OECD (the Organization for Economic Co-operation and Development) - the Czech Republic in 1995, Poland in 1996, Estonia and Slovenia in 2010. As member countries of the OECD, they started monitoring and measuring the educational outcomes because these may have an impact on the economic growth of the country. The most significant global education survey by OECD countries is PISA, (Programme for International Student Assessment). Another significant international long-term monitoring of education is organized by IEA (International Association for the Evaluation of Educational Achievement). It conducts a number of comparative studies of cross-national achievements, among them TIMSS (Trends in International Mathematics and Science Study) which includes testing in mathematics.

PISA is a triennial international survey first conducted in 2000 which is aimed at the evaluation of education systems worldwide by testing the skills and knowledge of 15-year-old pupils. Pupils are assessed in science, mathematics, reading, collaborative problem solving and financial literacy. The PISA assessment is always focused on one of the domains mentioned above to which is given greater emphasis. Mathematical literacy was the focus of the PISA survey in 2003 and 2012. It is

\footnotetext{
${ }^{1} 100 \%$ is the average of EU.
} 
interesting that the results of Czech pupils in 2012 are the worst in comparison to the pupils' results of other monitored countries (OECD, 2014a, b), whereas in 2003 Czech pupils were significantly more successful than Polish ones ${ }^{2}$ (OECD, 2004).

The other PISA surveys included mathematics problem solving as minor areas of assessment. The latest results in mathematics from PISA 2015 for the Czech Republic were the same as in 2012 - the worst result among the selected countries and just above the OECD average (OECD, 2018).

TIMSS is an international assessment of mathematics and science. TIMSS data have been collected every four years since 1995 at the $4^{\text {th }}$ and $8^{\text {th }}$ grades of basic schools. The scope of our interest is the results of the $8^{\text {th }}$ grades. From the selected countries only the Czech Republic and Slovenia are participating in TIMSS. The Czech Republic tested $8^{\text {th }}$ grades in TIMSS 1995, 1999, and 2007; the results show declines since 1995. Slovenian grade 8 pupils were tested in TIMSS 1999, 2007, 2011 and 2015. The first two results show a decline since 2007, when the results of Slovenian and Czech pupils were statistically comparable, while the performance of Slovenian pupils has been improving (Martin et al., 2008; Mullis et al., 2012, 2016).

The worsening of Czech pupils' results in international surveys and their comparison with the pupils' results in Estonia, Poland, and Slovenia lead us to reflect on possible causes and to look for the differences in approaches to mathematics education. One aspect of mathematics education is the mathematics curriculum. So we asked ourselves: What are the correspondences and differences in the national curriculum documents for lower secondary education (ISCED $2^{3}$ ) of the Czech Republic, Estonia, Poland and Slovenia?

\section{Theoretical Framework}

Comparative education was established as an international comparison of different education systems in several countries with the intention of gaining knowledge about the possibilities for improvement (Walterová, 2006). The curriculum is one of the main aspects of comparative education. According to the three-dimensional model for identifying various loci of comparative studies by Bray and Thomas (1995), we focus only on a very specific area - the national mathematics curriculum of four European countries by which pupils of lower secondary schools are educated.

A number of Czech research studies have been conducted in the past describing or comparing education systems in different countries (for example Ježková et al., 1996; Ježková \& Walterová, 1997). The first of these publications includes chapters devoted to Poland and Slovenia. Currently, we can use OECD ${ }^{4}$ and Eurydice ${ }^{5}$ publications which are mapping the education systems of EU countries with respect to different indicators. However, we do not know of any publication which compares the mathematics curriculum of the Czech Republic with any of the selected countries.

Walterová (1994) dealt with the issue of Czech curriculum in the international context. She described the international comparison of education as a hidden dimension in creating the key curriculum document National Programme for the Development of Education, i.e. a White Paper (MŠMT, 2001), which was the starting

\footnotetext{
${ }^{2}$ Estonia and Slovenia did not participate in PISA 2003.

${ }^{3}$ According to the International Standard Classification of Education (ČSÚ, 2008; UNESCO, 2018).

${ }^{4}$ https://www.oecd-ilibrary.org/

${ }^{5}$ https://eacea.ec.europa.eu/national-policies/eurydice/publications_cs
} 
point of the curriculum reforms in the Czech Republic after 2000. Walterová defined the curriculum in a broader context and presented the individual components of the curriculum documents. She also highlighted one of the trends in European countries in the 1990s - the transition to a participative model of curricular policy, i.e. shifting the responsibility for curriculum development from the state to the individual schools. This trend was related to the decentralization of education and to increased school autonomy. It manifested itself in all selected countries when they entered the European Union. These changes are described for example by Čerych et al. (1999) in the Czech Republic, by Karc (2003) and Wiśniewski (2007) in Poland, and by Walterová (2006) or Janík, Maňák and Knecht (2009) in general.

The means of uncovering problems in the curriculum is international testing (Walterová, 2006). Therefore, the decreased success rate of Czech pupils in the PISA and TIMSS surveys and the comparison of their results with the pupils of Estonia, Poland and Slovenia lead us to analyze the mathematics curriculum of these countries. The core of individual testing is different.

PISA is aimed at the evaluation of mathematical literacy, i.e. what pupils have learned for their future lives. Mathematical literacy has been already defined in 2003 as follows ${ }^{6}$ (OECD, 2004: p. 26): The capacity to identify and understand the role that mathematics plays in the world, to make well-founded judgments and to use and engage with mathematics in ways that meet the needs of that individual's life as a constructive, concerned and reflective citizen. Fig. 1 shows mathematical literacy in the context of a challenge or problem that arises in the real world. The inner box depicts the mathematical modelling cycle of the stages through which a problem solver moves when exhibiting mathematical literacy.

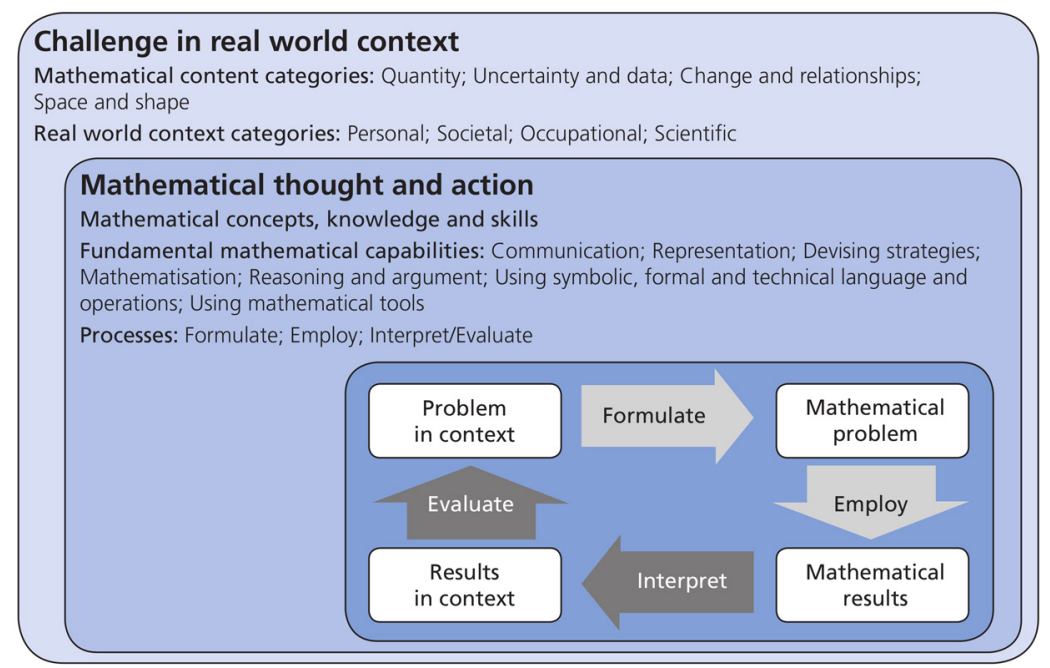

Fig. 1: The PISA model of mathematical literacy (OECD, 2013a: p. 26)

The TIMSS mathematics assessment is based on a content dimension (the topic areas or subject matter to be assessed within mathematics) and a cognitive dimension (thinking processes of pupils to be engaged while solving mathematics problems). In addition to TIMSS tests, pupils, pupils' parents, teachers and school principals complete the specific questionnaires. TIMSS follows a variant approach to the curriculum changes (Janík et al., 2010: p. 13; Maňák, Janík \& Švec, 2008: p. 21; Walterová, 2006: p. 199), i.e. TIMSS curriculum model is based on three aspects: the intended curriculum, the implemented curriculum, and the achieved

\footnotetext{
${ }^{6}$ In 2012 the definition was slightly modified (OECD, 2013a: p. 25).
} 


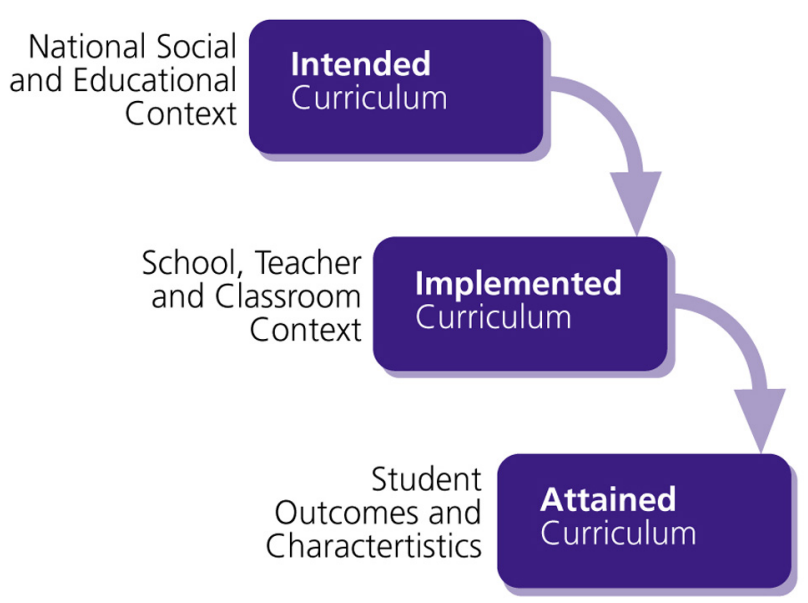

Fig. 2: The TIMSS curriculum model (Mullis et al., 2001: p. 3)

curriculum, see Fig. 2. The intended curriculum is examined primarily through the analysis of syllabi and the most widely used textbooks. The subject matter which is taught in all participating countries is tested. Information about the implemented and the achieved curriculum are obtained from the questionnaires completed by pupils and teachers and from the pupils' tests (Walterová, 2006).

Straková (2015) sees the aim of PISA surveys in influencing educational policy and the main purpose of TIMSS surveys as pedagogical research. Walterová (2006) sees the importance of TIMSS surveys in obtaining the basis for the determination of educational policy goals and in the possibility of following international trends in education. Teachers consider the decreased success rate of Czech pupils in international testing as one of the reasons for changing current curriculum documents (Janík et al., 2011).

It is necessary to realize that the curriculum is a very broad term. For instance, Walterová (1994) or Maňák, Janík and Švec (2008) provide possible definitions and classifications of the curriculum. In our research, we analyze only the official national documents of intended curriculum in which we can find among other things the learning content, time allotment, and educational goals and objectives.

Průcha $(1999,2012)$ considers comparing the learning content in school education of different countries as a necessity because the curricular policy is not a matter of a single country but it is becoming a subject matter of international interest and cooperation. He also points out that the educational content can be represented not only with the choice of school subjects and learning content but also with the time allotment for the individual educational areas. The goals of school education are an integral part of the curriculum documents. The curricula can be modernized and improved by analyzing them in the context of the content acquisition process. Janík, Maňák and Knecht (2009: p. 17) classify educational goals and objectives vertically by means of a goals pyramid - the highest are aims (reflecting the ideals of civilization and culture), then general goals (more specific content of education) and objectives (learning outcomes of the individual subjects) follow and their further specification. Bloom's taxonomy of Educational Objectives which was updated by Anderson, Krathwohl et al. (2001) is important for the formulation of objectives.

In this paper, we deal only with mathematics content and objectives and the general goals that are closely related to mathematics with the aim of comparing national curriculum documents for lower secondary education of the Czech Republic and other monitored countries. We mainly focus on differences in above-mentioned items and in other aspects of mathematics teaching. 


\section{The EDUCATION Systems}

The education systems in all four countries consist of pre-primary, basic, secondary, and tertiary education. The systems are slightly different regarding further division and time organizing. We will describe and compare the systems in this subsection with the emphasis on basic education which represents the scope of our interest. The education systems which we explore were followed up to 2016. The education systems with a focus on basic education of all four countries are schematically illustrated in Fig. 3 (MER, 2018a; MESS, 2018; MNE, 2018; MŠMT, 2018b; MŠMT, 2007).

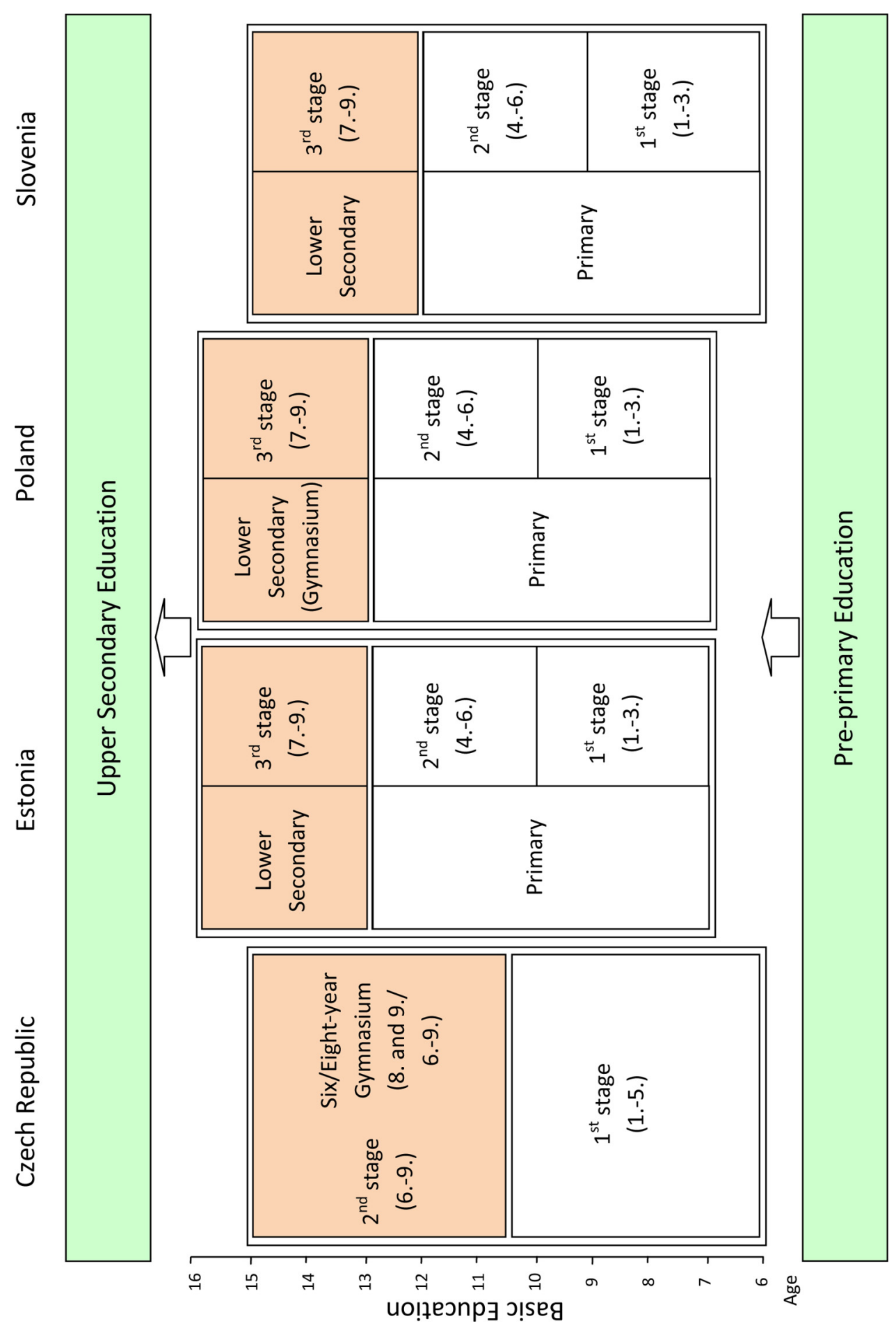

Fig. 3: Education systems in the Czech Republic, Estonia, Poland and Slovenia 
The Czech and Slovenian compulsory basic education starts at the age of six, the Estonian and Polish at the age of seven. Estonia, Poland ${ }^{7}$, and Slovenia have a three-stage basic education; Czech basic education is divided into two stages.

According to the International Standard Classification of Education (UNESCO, 2018), the scope of our interest is the second level (ISCED level 2) i.e. lower secondary education.

The third stage (grades 7 to 9 ) is considered as lower secondary education in Estonia, Poland, and Slovenia. In Poland, lower secondary education is covered by the gymnasiums (junior high schools) [gimnazjum]. Lower secondary education in the Czech Republic is the second stage of basic education (grades 6 to 9) and can be also realized in six-year gymnasiums (grades 8 and 9) or in eight-year gymnasiums (grades 6 to 9 ).

\section{ANALYSIS OF NATIONAL CURRICULUM DOCUMENTS}

The monitored countries entered the European Union in 2004 which significantly affected their approaches to education and curriculum documents. They implemented a two-level participative model of curricular policy according to the European Union's Member States. At the first level the binding national curriculum frameworks are developed, so-called national core curriculum; at the second level, the individual schools define the detailed school educational programmes by themselves, so-called school curriculum (Čerych et al., 1999). All schools are required to follow the national curriculum. The school curricula of the individual schools can differ with respect to the local conditions of a particular school; thus, their comparisons on an international scale dwindle in importance. Therefore, the scope of our interest is only the national curriculum.

\subsection{General DESCRIPTION}

The key document of the national curriculum in the Czech Republic has been the Framework Educational Programme for Basic Education (FEP BE) [Rámcový vzdělávaci program pro základní vzdělávání since $2005^{8}$ (MŠMT, 2007, 2017). The FEP BE is an open document which is periodically updated. We compare this document to the corresponding documents of Estonia - National curriculum for basic schools [Põhikooli riiklik õppekava] (HTM, 2011, 2014), of Poland - Podstawa programowa ksztatcenia ogólnego dla gimnazjów i szkól ponadgimnazjalnych, których ukończenie umożliwia uzyskanie świadectwa dojrzatości po zdaniu egzaminu maturalnego (MEN, 2008), and of Slovenia - Osnovo šolstvo (MIZŠ, 2018a).

\subsection{LEARNING AND EDUCATIONAL GOALS AND OBJECTIVES}

The learning and educational goals and objectives are first defined in general and second specifically regarding the concrete educational areas in the national curricula of the selected countries, i.e. related to the learning content of the educational area. We will focus on the learning and educational objectives both in general and in the educational area with respect to the subject mathematics.

\footnotetext{
${ }^{7}$ The ongoing reform of school system in Poland changes the basic education into eight-year basic schools with two grades.

${ }^{8}$ It has been taught according to the Framework in the Czech Republic since 2007 (MŠMT, 2018a).
} 


\subsubsection{SETTING OF GOALS AND COMPETENCIES}

The National Programme for the Development of Education, i.e. a White Paper (MŠMT, 2001), is the first binding government document published during the curriculum reforms in the Czech Republic after 2000 which were conducted in the manner of other European countries. The White Paper formulates the aims and recommendations, for instance:

... To promote the development of key competencies as an instrument for transforming the encyclopedic conception of education. To apply new methods of active teaching, namely project learning, various forms of cross-curricular integration, such as cross-curricular topics and projects, and other forms of extracurricular activities. To utilize these forms to introduce new topics into curricula... (MŠMT, 2001: p. 41).

Key competencies at the second stage of basic education represent the system of knowledge, skills, abilities, attitudes and values that are important to the individual's personal development and to the individual's role in society. At the basic education stage, the national concept of curriculum puts the emphasis on learning competencies, problem-solving competencies, communication competencies, social and personal competencies, civil competencies and working competencies (MŠMT, 2007: p. 12). All competencies are defined in general terms. Evidently, problemsolving competencies are those most related to the educational content of the subject field mathematics but this is not explicitly mentioned in the curriculum document.

Basic education should help pupils to form, shape and gradually develop their key competencies and provide them with dependable fundamentals of general education. Moreover, the scope and principles of basic education is to meet the 9 goals among them - "to stimulate and encourage pupils to creative thinking, logical reasoning and problem solving" (MŠMT, 2007: p. 11). Mathematics is not mentioned within these goals in the Czech curriculum.

A new Estonian general education curriculum with the emphasis on active child participation was established already in the 1990s (Afanasjev \& Lepmann, 2006). The current national curriculum (HTM, 2011), defines general goals and general competencies for basic schools; the competencies are also formulated in detail for each stage of the study. The goals are vaguely formulated. The educational content is more clearly defined by means of competence (HTM, 2011: pp. 3-5), which is the aggregate relevant knowledge, skills and attitudes that ensure the ability to operate creatively, in an enterprising way, and flexibly in a particular area of activity or field. Competencies are categorized as general competencies, competencies expected in stages of study, and subject field competencies.

One of the general competencies developed in pupils is mathematics, natural science and technology competence which is defined as the ability to use the language, symbols and methods characteristic of mathematical applications in school and everyday life (HTM, 2011: p. 4). Competencies in the third stage of study summarize in 14 items what the pupil should achieve at the end of the third stage. One of the achievements is directly related to mathematics:

The pupil is capable of resolving issues arising in various fields in everyday life that require use of mathematical thinking methods (logical thinking and spatial reasoning) and presentation methods (formulae, models, diagrams, graphs). (HTM, 2011: p. 10). 
Furthermore, it is pointed out that the pupils should have the ability to clearly and relevantly express themselves and to understand and interpret different types of texts.

The education reforms in Poland were conducted at the end of the 1990s. Gymnasium [gimnazjum] has been introduced as the lower secondary education corresponding with grades 7 to 9 of basic education in Estonia and Slovenia beginning with the school year of 1999/2000 (Eurydice, 2008: p. 6). The core curriculum document (MEN, 2008) is common for gymnasiums and post-gymnasium schools. In this document, there are formulated three very general goals of education and the most important skills which should be achieved by the pupils. In fact, these requirements are equivalent to the competencies in the curriculum documents of other countries. One of the main goals of learning and education is to help the pupils develop their mathematical thinking which is defined as the ability to use mathematical methods in everyday life and to make decisions based on mathematical reasoning (MEN, 2008: p. 1).

Slovenian national curriculum defines 15 goals of basic education, among them the development of literacy and understanding of the text in natural sciences, mathematics, informatics, social sciences and arts. Mathematical literacy is defined as the ability to use mathematical way of thinking in solving real-life problems (Brezovar et al., 2013: p. 4). This includes the ability and readiness for using mathematical thinking modes (logical thinking and spatial reasoning) and presentation modes (formulae, models, constructions, graphs, and diagrams).

General goals of basic education are similar in all four countries. The set of basic competencies is formulated in the Czech Republic and Estonia and the achievement of these competencies is considered as one of the main goals of basic education. In Poland, basic education is based on the development of the specific areas; these areas are equivalent to the Czech and Estonian competencies. The concept of Slovenian curriculum is slightly different. There are more detailed descriptions of various goals but the setting of basic competencies is missing. In general, the goals defined in the Slovenian curriculum are more or less the same as in other countries. The Estonian national curriculum seems to be the most elaborate and detailed document; competencies expected in stages of study are introduced in addition to general and subject field ones. The common competencies for the third and fourth stage, i.e. for gymnasiums and post-gymnasium schools, are presented in the Polish curriculum. The curriculum documents in the Czech Republic and Slovenia define the competencies for the entire basic education, i.e. the competencies are common for both the primary and lower secondary education.

Mathematics is mentioned explicitly in the national curricula of Estonia, Poland, and Slovenia. Moreover, at the end of the third stage of study in Estonia, the emphasis is put on the ability to clearly and relevantly express oneself. Slovenian national curriculum introduces mathematical competence as one of the goals, but very vaguely. Polish national curriculum focuses on mathematical thinking.

\subsubsection{MAThematics obJeCtives}

Mathematics objectives are described in the following documents: the Framework Educational Programme for Basic Education (MŠMT, 2007, 2017) in the Czech Republic, in the third appendix of National curriculum for basic schools (MER, 2018b) in Estonia, in Podstawa programowa ksztatcenia ogólnego dla gimnazjów i szkól ponadgimnazjalnych, których ukończenie umożliwia uzyskanie świadectwa dojrzatości po 
zdaniu egzaminu maturalnego (MEN, 2008) in Poland, and in Matematika - Učni načrt (MIZŠ , 2018b) in Slovenia.

In general, the number of mathematics objectives is shared by all curriculum documents, and their descriptions are more or less the same (the objectives are very similar, just formulated differently). The objectives which are not common for all four countries are unique.

Firstly, let us focus on the common features in the mathematics objectives of the selected countries. The expected objectives after completing the basic education are summarized in Tab. 1.

Tab. 1: Common features in mathematics objectives

\begin{tabular}{lcccc}
\hline Objective & CR & Est & Slo & Pol \\
\hline $\begin{array}{l}\text { Create and use mathematical models in order to solve } \\
\text { problems in different fields of everyday life. }\end{array}$ & $\bullet$ & $\bullet$ & & $\bullet$ \\
\hline $\begin{array}{l}\text { Apply mathematical knowledge and skills in practical } \\
\text { activities - for instance estimating, measuring and } \\
\text { comparing sizes and distances, orientation. }\end{array}$ & $\bullet$ & $\bullet$ & $\bullet$ \\
\hline $\begin{array}{l}\text { Interpret and present information in the form of text, } \\
\text { graphs, tables. }\end{array}$ & & $\bullet$ & \\
\hline Use abstract, logical thinking, and critical judgment. & $\bullet$ & $\bullet$ & $\bullet$ \\
\hline Justify and analyze problems, formulate hypotheses. & $\bullet$ & $\bullet$ & & $\bullet$ \\
\hline Compile and use solution strategies. & $\bullet$ & $\bullet$ & & $\bullet$ \\
\hline $\begin{array}{l}\text { Have knowledge of mathematical terms and create } \\
\text { a system of terms. }\end{array}$ & $\bullet$ & $\bullet$ & $\bullet$ & \\
\hline Trust in their own problem-solving skills and abilities. & $\bullet$ & $\bullet$ & $\bullet$ & \\
\hline
\end{tabular}

Secondly, let us mention what is unique in the individual curriculum documents of the selected countries.

Basic school pupils in the Czech Republic

- develop their memory by performing numerical calculations and learn necessary mathematical formulas and algorithms;

- learn to express themselves precisely and succinctly by using the language of mathematics, including mathematical symbols, and by performing analyses and keeping records during problem-solving, and by perfecting their graphic abilities;

- learn to co-operate while solving problems and applied tasks.

Basic school pupils in Estonia

- use computer programs and other tools in studying mathematical;

- understand the value of and enjoy mathematics.

Basic school pupils in Slovenia

- receive and experience mathematics as a cultural value.

The most detailed description of general mathematics objectives is given in the Czech curriculum document (MŠMT, 2007, 2017); in comparison, the Polish curriculum document mentions them very briefly. In the Slovenian curriculum, besides general mathematics objectives, there are defined global objectives related to each topic in mathematics. These global objectives are very detailed, for instance, having a basic knowledge of algebraic expressions. The general objectives of mathematics education are also defined in the Estonian curriculum. Moreover, the mathematical 
learning and educational objectives, after completing every educational stage, are specified there.

\subsection{ThE SYLLABUSES OF MATHEMATICS}

The learning outcomes and content of mathematics in lower secondary education are described in the following documents: the Framework Educational Programme for Basic Education (MŠMT, 2007; 2017) in the Czech Republic, in the third appendix of National curriculum for basic schools (MER, 2018b) in Estonia, in Podstawa programowa ksztatcenia ogólnego dla gimnazjów i szkól ponadgimnazjalnych, których ukończenie umożliwia uzyskanie świadectwa dojrzatości po zdaniu egzaminu maturalnego (MEN, 2008) in Poland, and in Matematika - Učni načrt (MIZ ̌́, 2018b) in Slovenia.

In the Czech Republic, the educational area is called Mathematics and its application. The minimum time allotment for the educational area Mathematics and its application at the second stage of basic education is 15 teaching hours ${ }^{9}$ per week at all grade levels of basic education. First, the characteristics of the educational area with the emphasis on the individual thematic parts are given. The description of the objectives of the educational area and its educational content follows. The educational content of the educational field comprises the expected outcomes and the subject matter. Expected outcomes are binding at the end of grade 9 . The subject matter is supposed to be a means to achieve the expected outcomes (MŠMT, 2007: p. 16) and is recommended to schools for distribution and further modifying.

The educational content of Mathematics and its application is divided into four thematic parts: Numbers and Variables; Dependencies, Relations and Working with Data; Two- and Three-dimensional Geometry; Non-Standard Application Exercises and Problems.

In the Estonian curriculum, the weekly number of lessons for compulsory subjects in basic school for all stages of study is specified. The subject field Mathematics is taught in all grades of basic education and in the third stage of study, it is 13 lessons per week. Furthermore, the distribution of weekly hours of subjects within stages is specified in the school curriculum along with expected learning outcomes and learning and educational objectives to be achieved (MER, 2018b: pp. 1-2). The description of the subject field is provided, and mathematics learning and educational objectives, learning outcomes, and learning content are specified in the syllabus of mathematics.

The subject field of Mathematics in the third stage of study is divided into five parts: Calculation and Data; Percentages; Algebra; Functions; Geometry.

In Poland, the educational area is called Mathematics [Matematyka]. The minimum number of teaching hours by this subject in the 3 -year period at lowersecondary schools is $385^{10}$ (Eurydice, 2014). The learning outcomes are specified in the syllabus of mathematics for each thematic part. The learning content is not specifically defined in the curriculum document.

The educational content of Mathematics is divided into eleven thematic parts: Rational Numbers (positive); Rational Numbers (positive and negative); Powers; Roots; Percentages; Algebraic Expression; Equations; Graph of a Function; Descriptive Statistics and an Introduction to Probability theory; Two-dimensional Figures; Solids.

\footnotetext{
${ }^{9}$ One teaching hour (lesson) takes $45 \mathrm{~min}$.

${ }^{10}$ This number of hours corresponds to approximately 4 teaching hours per week.
} 
The Slovenian curriculum provides the most detailed description of the syllabus of Mathematics [Matematika]. The recommended number of hours for each theme of mathematics is provided; the total number of hours for mathematics is 140, 140, and $128^{11}$ hours for the grades, 7, 8, and 9, respectively. It defines compulsory and optional learning outcomes (in Tab. A4 in the Appendix the optional ones are written in italic type). For all educational periods, the learning outcomes and content are suggested.

In every educational period, there are three main themes in Mathematics: Geometry and Measurement; Arithmetic and Algebra; Other Content. All themes are divided into thematic parts. For each theme, the global objectives of the educational period are defined. The learning outcomes and content are divided into blocks according to individual grades; the division is only recommended.

The extensiveness of curriculum structure regarding the learning outcomes and content does not allow us to describe all parts of the syllabus of mathematics. Let us focus only on geometry in all four curricula and describe more precisely the learning content and expected outcomes of this part of the subject field of mathematics.

We recommend that the reader follows Tab. A1, A2, A3, and A4 in the Appendix where the learning outcomes and content in mathematics with the emphasis on geometry are summarized and categorized according to the subtopics for each country. The learning outcomes and content for Slovenia are also classified according to grades in which they should be realized.

The Czech Republic introduces the subject matter which is only recommended (MŠMT, 2017: p. 15). The thematic part related to geometry is Two- and Threedimensional Geometry and the learning content is divided into four parts (twodimensional figures, characteristics of two-dimensional measurements, three-dimensional figures, and construction tasks). The teachers have to fulfil the binding learning outcomes which are defined quite vaguely; only from the recommended learning content can it be derived how to achieve them. Estonia also has a brief description of the learning outcomes and content of the part Geometry. It is not divided into any subtopics. Poland does not present the learning content at all but has a very detailed description of the learning outcomes which can substitute for it. The Polish thematic parts which are in the scope of our interest are Two-dimensional Figures and Solids. As we can see from Tab. A4 Slovenia provides the most detailed description of the syllabus of mathematics. The theme Geometry and Measurement is divided into two thematic parts - Geometric Terms and Transformations. Moreover, the learning outcomes and content are described individually for each grade.

If we compare the individual learning outcomes and content of the selected countries, we can find several distinctions. Regarding two-dimensional geometry, all curriculum documents point out several two-dimensional figures which should be taught. All countries particularly refer to triangles, quadrilaterals (trapeziums and parallelograms), and regular polygons. In addition to these Poland and Slovenia also mention rhombi and only Slovenian learning outcomes and content distinguish kites within quadrilaterals. The other interesting topics in two-dimensional geometry are angles. Only Poland has the recognition of central angles among the learning outcomes. Only Estonia refers to trigonometric functions of acute angles. Regarding three-dimensional geometry all curriculum documents mention calculation of the volume and surface area of solids among learning outcomes. Vertical parallelepipeds are considered among the solid figures only in Estonia; in all four countries the list

\footnotetext{
${ }^{11}$ These numbers of hours correspond to approximately 4 teaching hours per week.
} 
of solid figures consists of cube, cuboid, vertical prism, pyramid, cylinder, cone, and sphere. Only the Slovenian curriculum describes additional learning outcomes and content related to solids - for example to create models of solids and draw their nets. Only Estonian curriculum document reflects the usage of technological tools in the learning outcomes to discover regularities and formulate hypotheses. The Slovenian learning outcomes place emphasis on the calculation with and without calculators.

\section{TeAching Methods, ASSESSMEnt, AND OTHER ASPECTS OF THE NATIONAL CURRICULA}

The description of teaching methods in the Czech curriculum is limited only to the recommendation to apply different methods of active teaching, namely project learning, various forms of cross-curricular integration and other forms of extracurricular activities. The specific teaching methods for mathematics are not described.

The Estonian curriculum provides a little more regarding the description of teaching methods:

A diverse selection of study methods is used with emphasis on active study methods: independent work, conversation, debate, discussion, work in pairs, project study, group work. (MER, 2018b: p. 6).

It is worth mentioning that homework is also included in the curriculum as one of the important study activities.

In the Slovenian curriculum, there are added didactic recommendations to each educational period and to each theme - for example, regarding the theme Geometry and Measurement, there is advice provided on which models can be selected for the representation of the studied figures (edges, faces, solids). Furthermore, there are some specifications like: "we solve the tasks using trial and deliberation, not formally by solving equations in the $7^{\text {th }}$ grade. We consider formal solving of equations in the $9^{\text {th }}$ grade" (MIZŠ, 2018b: p. 46). The Slovenian curriculum puts emphasis on the integration of education with everyday life to make it more understandable and reasonable to pupils. It is necessary to apply various learning styles, different methods and formats, didactic aids, and modern technologies. It is essential to perceive the learning content in depth over the mere recall of symbols. At the same time, it is highlighted that rote learning plays an important role in the learning process and in developing computational skills and that making it automatic is necessary.

The Polish curriculum does not mention teaching methods, only several didactic recommendations which are divided according to the age of pupils can be found there.

The Estonian and Slovenian curriculum briefly comments on pupils' assessment in mathematics.

The description of the assessment of learning outcomes is specified in the general part of the Estonian curriculum. Detailed assessment procedures are introduced, and formative assessment and summarizing grading are used in assessment. In formative assessment, the primary focus is on comparing a pupil's development with his or her previous accomplishments. In summarizing grading, a pupil's accomplishments are compared with required learning outcomes. Both result and process are assessed in case of practical assignments and problems (MER, 2018b). 
A mention of pupils' assessment can be found in the Slovenian curriculum document too. In addition to written and oral examination, it is recommended to use other forms of assessments - presentation of seminar works and projects, mathematical and statistical research, practical tasks, and monitoring of homework (which is considered as an important part of the learning process because of pupils' selfeducation, developing their good work habits, persistence, and precision). The oral exam should assess pupils' knowledge which can be hardly examined in the written tests.

The Czech Republic and Poland do not mention pupils' assessment in mathematics in the national curriculum documents.

The final examinations in mathematics can provide significant extrinsic motivation for learning for the pupils. In Estonia, Poland, and Slovenia all ninth-grade pupils have to take the unified basic school final examination in mathematics established by law.

In Slovenia, the results are considered as additional information about the level of pupils' knowledge and do not have any bearing on the grades (Eurydice, 2017; Wiseman, 2010). A satisfactory grade on the examination is not a necessary condition for graduation from basic school but the results are taken into account in entrance examinations to secondary schools.

In Poland, at the end of lower-secondary education pupils take a compulsory external examination which has a strong bearing on admission to upper-secondary schools (Eurydice, 2014). Examination results are related both to schools' effectiveness and pupils' accomplishments (Anczewska \& Charzyńska, 2012). They help to revise curricula and encourage the introduction of more effective teaching methods. The final examination is not a necessary condition for graduation from basic school.

In Estonia, the national examinations take place at the end of basic education and have a certification function (Santiago et al., 2016), i.e. passing the basic school final examination is the condition for graduation from basic school and completing the third stage of study (MER, 2018b: p. 19). Results of these examinations are used by some selective upper secondary schools for admission purposes. Thus, national assessments do have formal consequences for students. Estonia reports a higher level of use of central student assessments for formative purposes than for summative purposes. In PISA 2012 (OECD, 2013b), for example, Estonia reported more use of assessment data than other OECD countries to make decisions about student retention or promotion or to identify aspects of instruction or the curriculum that could be improved (OECD, 2016).

In the Czech Republic, there is no unified basic school final examination. In addition to international PISA and TIMSS surveys which are used as an assessment tool in the Czech Republic, there are assessments carried out by the Czech School Inspectorate. These assessments are not held every year and not in all basic schools. The sole extensive state-guaranteed examination in mathematics for grade 9 pupils is the unified entrance examination to secondary schools which is taken only by pupils who want to enter secondary schools. This examination has been used since the 2016/2017 school year.

\section{Discussion And Conclusion}

Comparing the curriculum documents of the Czech Republic with the curriculum documents of Estonia, Poland, and Slovenia we can identify several significant differences: 
- The minimum time allotment in mathematics in lower secondary schools is the lowest in the Czech Republic.

- The general goals in the Czech curriculum do not put proper emphasis on mathematics education.

- In the Czech curriculum, there is no mention of the importance of the self-reliant systematic home preparation of pupils.

- There is no national assessment tool in the Czech Republic which compares pupils' performance in mathematics at the end of lower secondary school education.

- The learning outcomes in the Czech curriculum are specified only briefly; the learning content is neither binding nor concrete enough.

The time allotment is defined for the entire educational period, in the Czech Republic for the grades 6 to 9 and in Estonia, Poland, and Slovenia for the grades 7 to 9 . The distribution of hours between the grades is left to the school principals. In reality, the school shall use the available time allotment. ${ }^{12}$

The time allotment for mathematics education is the lowest in the Czech Republic in comparison with the monitored countries (see Tab. 2, in which the average time allotments per week in one year of study are compared; the numbers present a number of mathematics lessons, one lesson takes $45 \mathrm{~min}) .{ }^{13}$

Tab. 2: The average time allotment for mathematics per week in lower secondary schools

\begin{tabular}{cccc}
\hline Czech Republic & Estonia & Poland & Slovenia \\
\hline 3.75 & 4.3 & 4 & 4 \\
\hline
\end{tabular}

Based on some empirical research (e.g. Lavy, 2015), there is a relationship between the amount of time that an individual spends on studying, and the amount of knowledge and skills that he/she can mine from it. According to several studies (e.g., Blank, 2013; Desimore \& Long, 2010), student performance increases with more instructional time. On the other hand, TIMSS research shows that there is no direct correlation between time allotment in school and pupils' knowledge, but "it depends on how effectively and efficiently the time is used" (Mullis, Martin \& Loveless, 2016: p. 46). However, the information from TIMSS research led to a recommendation to increase the number of primary school hours in Iceland in the past (Walterová, 2006: p. 200). According to Cattaneo, Oggenfuss and Wolter (2016: p. 14): "prescribed hours also might not adequately depict the reality in schools" and "the additional instructional time has a significant impact on learning outcomes measured with PISA test scores, but the effectiveness of an additional hour of instruction is only between thirty to forty percent of the impact that they would expect from an average hour of instruction". Other surveys indicate that the additional instructional time for mathematics has a positive effect, though they also mention other significant aspects such as the classroom setting (Rivkin \& Schiman, 2013) or the teacher quality (Woessmann, 2016) at the same time. Therefore, it

\footnotetext{
${ }^{12}$ According to questionnaires completed by teachers during TIMSS, the actual average number of mathematics lessons in the $8^{\text {th }}$ grade of basic education was $3 \mathrm{hrs} .14 \mathrm{~min}$./week in 2007 and $3 \mathrm{hrs} .34 \mathrm{~min}$./week in 2015 (Mullis, Martin \& Loveless, 2016). Thus, a slight increase of the time allotment can be observed.

${ }^{13}$ On the other hand, the total time allotment for mathematics for the grades 6 to 9 recommended by the Ministry of Education, Youth and Sport is 18, i.e. 4.5 lessons per week in one year of study (MŠMT, 2011). It is worth mentioning that mathematics in lower secondary schools in Czechoslovakia/Czech Republic was being taught 5 lessons per week until 1991 and at least 4 lessons per week between 1991 and 2005 (MŠ, 1987; MŠMT, 1991; MŠMT, 1996).
} 
cannot be simply said that the lowest time allotment is the cause of the decreased success rate of Czech pupils in international testing.

The decentralization of the Czech education system after 2000 is related to the transfer of emphasis from the content of the curriculum to key competencies. Janík, Maňák and Knecht (2009) found focusing on key competence to be a new positive element of basic education goals. However, Slavík and Janík (2012) pointed out the problem of emptying the content.

We have found that the development of mathematics competence, understanding mathematical texts, using mathematical symbols and the like belong among the general goals of education of lower secondary schools in all monitored countries except the Czech Republic. Including or not including these skills among general goals and competencies expresses their importance in education. The natural consequence of their inclusion in the curriculum can be a gradually increasing integration of the development of mathematical competencies (such as using diagrams, percentages, etc.) in other subjects. We also consider the ability of pupils to understand technical terms and to express themselves correctly as crucial (not only for mathematics). Understanding text is one of the general goals in the curriculum document of Slovenia; the ability to formulate mathematical ideas is among the general competencies of education in Estonia. A similar general goal or competency is missing in the Czech curriculum.

Mathematics education requires continuous and systematic preparation of pupils. This can be achieved through solving assigned homework problems. The impact of homework as a part of the learning process was examined in several studies. The strength of the relationship between homework and pupil achievement in mathematics is not yet fully clear; the results of studies are inconsistent. Some researchers found a positive relationship (e.g., Cheema \& Sheridan, 2015; Abdelfattah \& Lam, 2018), some studies generated contradicting findings (Cooper, Robinson \& Patall, 2006; Dettmers, Trautwein \& Lüdtke, 2009). Dettmers, Trautwein and Lüdtke (2009) showed in their study rooted in PISA 2003 a significant positive relationship between the students' scores in mathematics and the time spent doing homework at the group level. On the other hand, there was a negative relationship at the student level across countries. Based on the results of TIMSS surveys, Güven (2019) concluded that the frequency of homework significantly affects pupil achievement in the $8^{\text {th }}$ grade but not in the $4^{\text {th }}$ grade. Similarly, Cooper, Robinson and Patall (2006) found that homework-achievement relationship differs at different grade levels.

Homework enables pupils to develop their own initiative and to deepen and strengthen their knowledge. The curriculum documents of Estonia and Slovenia mention it; in the Czech curriculum, these aspects are not considered. On the contrary, the current tendencies (especially the pressure from parents, and not only in the Czech Republic) are against it - pupils should not be overloaded with homework (ČŠI, 2018; Güven, 2019). PISA 2012 showed that pupils in Poland and Estonia spend about twice more time with homework than pupils in the Czech Republic and Slovenia (OECD, 2014c). Abdelfattah and Lam (2018), based on the results of TIMSS in 15 Arab countries, determined that longer homework (taking more than 60 minutes) is annoying for the pupils, while shorter and less frequent homework (1 to 4 times a week) reflects an important way to improve their achievement. According to Maňák (1992), pupils must be sufficiently motivated to do homework. The perceived low motivation of current Czech pupils is also considered to be one of the factors that caused a statistically significant worsening of Czech pupils in PISA surveys in recent years (ČŠI, 2016). 
The Czech educational policy declares the necessity of national testing at all levels of education as the main tool for monitoring the outcomes of education. This need is closely interconnected with increasing school autonomy (MŠMT, 2001: p. 92). The Czech Republic has not developed a national testing system yet (Dvořák, 2015). An exception is the unified and compulsory entrance examination to secondary schools beginning with the 2016/2017 school year which covers Czech language and mathematics. The school principals can create further conditions for admission to secondary schools but at least $60 \%$ of the results of the unified entrance examination to secondary schools must be taken into account by law (561/2004 Sb.). However, the entrance examinations are not compulsory for everybody; only pupils who wish to continue their studies are taking them. On the contrary, in Estonia, Poland and Slovenia, all pupils must take the unified final examination at the end of the lower secondary school (Eurydice, 2009).

The majority of European countries have introduced regular national examinations in an attempt to increase the effectiveness and efficiency of their education systems. In the school year 2008/2009, only the German-speaking community of Belgium, the Czech Republic, Greece, Wales and Liechtenstein did not administer national tests in compulsory education.

The majority of learning outcomes and learning content is the same in all countries; nevertheless, distinctions can be found. Only Estonian curriculum document mentions the usage of technological tools in the learning outcomes. In the Slovenian curriculum document, it is pointed out several times to use or not to use calculators in the tasks. The use of calculators and technologies is also mentioned in the Czech curriculum, but not in relation to teaching geometry.

In general, we can say the Czech school curricula of the individual schools are probably more difficult to create than the school curricula of the other countries because the learning outcomes in the Czech national core curriculum are defined very briefly. Especially, the Slovenian curriculum document could serve as a good example of a detailed, well-elaborated material.

Slovenia provides the most detailed description of the syllabus of mathematics. This is the main difference from other countries of the European Union where there has been an evident trend of moving away from a detailed description of subject matter in curriculum documents since the 1990s (Ježková \& Walterová, 1997). A detailed description can be the starting point for teachers who can simply follow the learning content from the curriculum documents in their classes. Moreover, the division of the topics according to individual grades can help Slovenian teachers orient themselves in the extensive content of the subject field of mathematics. This can be useful especially for novice teachers. We have found Slovenian curriculum to be a very inspiring source for the Czech curriculum documents regarding their prospective modifications.

The transformation of goals and objectives into the learning content is the basis for the successful implementation of the educational process (Janík, Maňák $\&$ Knecht, 2009). However, the inaccurate specification of mathematics learning outcomes and learning content gives great freedom to schools (teachers) to determine this learning content. It is necessary to realize that the teacher is responsible for the final form of the curriculum, i.e. the implemented model of curriculum (Janík, Maňák \& Knecht, 2009). That's why an important aspect of each curriculum reform is its acceptance by teachers (Maňák, Janík \& Švec, 2008; Pešková, Spurná \& Knecht, 2017; Roter, 2003). Dvořák (2015) points out the problem of conceptual framework of the national curriculum in a participative model of curricular policy. 
Straková (2007) described the teachers' opinion on curriculum reform in the Czech Republic after 2000 as inconsistent. Janík (2013) states the implementation of the current Czech curriculum reform has resulted in mere formalism. The problematic and slow adoption of reforms in the 1990s in Slovenia is described by Ježková et al. (1996).

Teachers play an irreplaceable role in the education process and can significantly influence the pupils (Martínková, Goldhaber \& Erosheva, 2018; Akiba, LeTendre \& Scribner, 2007; Blomeke, Olsen \& Suhl, 2016). According to a survey by Earnets and Amador (2019), the teachers cover the subject matter to varying extent using curriculum documents. The question arises whether the curriculum documents are to bind or to allow some level of latitude for teachers.

We have identified the specific differences in the national curriculum documents for lower secondary schools of the selected countries. We cannot conclude that only curriculum documents have an impact on the quality of education and on better results of pupils in the national testing. We also do not know how the curriculum documents are used in practice and if and how the teachers work with them. In general, there are even more aspects which can improve or worsen pupils' results - inner factors (pupils' aptitude, handicaps etc.) and outer factors (social environment, family, teacher etc.). The curriculum document is only one component which can influence the school instructions.

\section{ACKNOWLEDGEMENT}

The paper has been supported by the project PROGRES Q17 Teacher preparation and teaching profession in the context of science and research and by Charles University Research Centre program No. UNCE/HUM/024.

\section{REFERENCES}

Abdelfattah, F. \& Lam, J. (2018). Linking homework to achievement in mathematics: An examination of $8^{\text {th }}$ grade Arab participation in TIMSS 2015. International Journal of Instruction, 11(4), 607-624. https://doi.org/10.12973/iji.2018.11438a

Akiba, M., LeTendre, G. K. \& Scribner, J.P. (2007). Teacher quality, opportunity gap, and national achievement in 46 countries. Educational Researcher, 36(7), 369-387. https://doi.org/10.3102/0013189X07308739

Afanasjev, J. \& Lepmann, T. (2006). The development of the Estonian national school mathematics curriculum in 1990-2005. Online submission, paper presented at the Teaching mathematics: Retrospective and perspectives international conference $\left(7^{\text {th }}\right.$, Tartu, Estonia, May 12-13). Available from https://eric.ed.gov/?id=ED495299

Anczewska, M. \& Charzyńska, K. (2012). Educational assessment of pupils in Poland. SA-eDUC JOURNAL, 9(1), 1-9.

Anderson, L. W. \& Krathwohl, D. R. (Eds.). (2001). A taxonomy for learning, teaching, and assessing. A revision of Bloom's taxonomy of educational objectives. New York: Longman.

Blank, R. K. (2013). Science instructional time is declining in elementary schools: What are the implications for student achievement and closing the gap? Science Education, 97(6), 830-847. https://doi.org/10.1002/sce.21078 
Blomeke, S., Olsen, R. \& Suhl, U. (2016). Relation of student achievement to the quality of their teachers and instructional quality. In T. Nilson \& J.-E. Gustafsson (Eds.), Teacher quality, instructional quality and student outcomes. A series of in-depth analyses based on data of the international association for the evaluation of educational achievement (IEA), Volume 2 (21-50). Cham: Springer Open.

Bray, M. \& Thomas, R. M. (1995). Levels of comparison in educational studies. Different insights from different literatures and the value of multilevel analyses. Harvard

Educational Revue, 65(3), 472-490.

https://doi.org/10.17763/haer.65.3.g3228437224v4877

Brezovar, D., et al. (2013). Matematična kompetenca in osnovne kompetence $v$ znanosti in tehnologiji. Ljubljana: Andragoški center Slovenije. Available from https://mm.acs.si/pismenost/doc/2013/Matematika_znanost_tehnologija.pdf

Cattaneo, M. A., Oggenfuss, Ch. \& Wolter, S. C. (2016). The more, the better? The impact of instructional time on student performance. IZA Discussion Paper, No. 9797, $1-22$.

Cheema, J. R. \& Sheridan, K. (2015). Time spent on homework, mathematics anxiety and mathematics achievement: Evidence from a US sample. Issues in Educational Research, 25(3), 246-259.

Cooper, H., Robinson, J. \& Patall, E. (2006). Does homework improve academic achievement? A synthesis of research, 1987-2003. Review of Educational Research, $76(1), 1-62$.

Čerych, L., et al. (1999). Czech education and Europe. Prague: Education policy association.

ČSÚ. (2008). Metodika. Mezinárodní klasifikace vzdělávání (ISCED 97). Praha: Ceský statistický úřad. Available from https://www.czso.cz/documents/10180/20536112/ 022608.pdf/c483e906-0604-4212-824e-acc7cd9b2cf3?version=1.0

ČŠI. (2016). Rozdíly mezi školami v matematické gramotnosti. Sekundární analýzy výsledku mezinárodního šetřeni PISA. Praha: ČS̆I. Available from https://www.csicr.cz/Csicr/media/Prilohy/PDF_el._publikace/ Mezin\%c3\%a1rodn\%c3\%ad\%20\%c5\%a1et\%c5\%99en\%c3\%ad/

PISA_SA_rozdily_matgra.pdf

ČŠI. (2018). K povinnosti vypracovávání domácích úkolů. Available from http://www.vzdelavacisluzby.cz/dokumenty/banka-souboru/3636481.pdf [retrieved March 2019]

Desimone, L. M. \& Long, D. (2010). Teacher effects and the achievement gap: Do teacher and teaching quality influence the achievement gap between black and white and high-and low-SES students in the early grades. Teachers College Record, 112(12), 3024-3073.

Dettmers, S., Trautwein, U. \& Lüdtke, O. (2009). The relationship between homework time and achievement is not universal: evidence from multilevel analyses in 40 countries. School Effectiveness and School Improvement, 20(4), 375-405.

https://doi.org/10.1080/09243450902904601

Dvořák, D. (2015). Proměny kurikulárního diskurzu: o aktérech, standardech a ledních medvědech. In D. Greger (Ed.), Srovnávací pedagogika: Proměny a výzvy (101-117). Praha: Univerzita Karlova v Praze, Pedagogická fakulta. 
Earnets, D. \& Amador, J. M. (2019). Lessons planimation: prospective elementary teachers' interactions with mathematics curricula. Journal of Mathematics Teacher Education, 22(1), 37-68. https://doi.org/10.1007/s10857-017-9374-2

Eurostat. (2017a). Purchasing power adjusted GDP per capita. Available from https://ec.europa.eu/eurostat/tgm/table.do?tab=table\&init $=1 \&$ plugin $=1 \&$ pcode=sdg_10_10\&language $=$ en [retrieved November 2018]

Eurostat. (2017b). GDP per capita in PPS. Available from https://ec.europa.eu/eurostat/tgm/table.do?tab=table\&init=1\&language=en\& pcode $=$ tec00114\&plugin $=1$ [retrieved November 2018]

Eurydice. (2008). The system of education in Poland. Warszawa: Eurydice.

Eurydice. (2009). National testing of pupils in Europe: Objectives, organisation and use of results. Brussels: Education, Audiovisual and Culture Executive Agency. https://doi.org/10.2797/18294

Eurydice. (2014). The system of education in Poland. Warszawa: Eurydice.

Eurydice. (2017). The education system in the Republic of Slovenia 2016/2017. Ljubljana: Eurydice.

Güven, U. \& Akçay, A. O. (2019). Trends of homework in mathematics: Comparative research based on TIMSS study. International Journal of Instruction, 12(1), 1367-1382. https://doi.org/10.29333/iji.2019.12187a

HTM. (2011). Põhikooli riiklik õppekava. Tallin, Toompea: Haridus- ja Teadusministeerium. Available from https://www.riigiteataja.ee/akt/114012011001 [retrieved November 2018]

HTM. (2014). National curriculum for basic schools. Available from https://www.riigiteataja.ee/en/eli/524092014014/consolide [retrieved November 2018]

Janík, T., et al. (2011). Kvalita školy a kurikula: od expertního šetření ke standardu kvality. Praha: Národní ústav pro vzdělávání, školské poradenské zařízení a zařizení pro další vzdělávání pedagogických pracovníků (NÚV), divize VÚP.

Janík, T. (2013). Od reformy kurikula k produktivní kultuře vyučování a učení. Pedagogická orientace, 23(5), 634-663. https://doi.org/10.5817/PedOr2013-5-634

Janík, T., Maňák, J. \& Knecht, P. (2009). Cíle a obsahy školního vzdělávání a metodologie jejich utváření. Brno: Paido.

Janík, T., Maňák, J., Knecht, P. \& Němec, J. (2010). Proměny kurikula současné české školy: vize a realita. Orbis scholae, 4(3), 9-35.

https://doi.org/10.14712/23363177.2018.109

Ježková, V., et al. (1996). Vzdělávaci systémy v zahraničí. Praha: Karolinum.

Ježková, V. \& Walterová, E. (1997). Vzdělávání v zemích Evropské unie. Praha: Pedagogická fakulta Univerzity Karlovy, Centrum evropských studií.

Karc, E. (2003). System zarządzania oświata a reforma edukacji w Polsce. In J. Prokop (Ed.), K otázkám srovnávací pedagogiky (165-170). Praha: Karolinum.

Lavy, V. (2015). Do differences in schools' instruction time explain international achievement gaps? Evidence from developed and developing countries. The Economic Journal, 125(588), F397-F424. https://doi.org/10.1111/ecoj.12233

Maňák, J. (1992). Problematika domácích úkoli na základni škole. Brno: Masarykova univerzita v Brně. 
Maňák, J., Janík, T. \& Švec, V. (2008). Kurikulum v současné době. Brno: Paido.

Martin, M. O., et al. (Eds.). (2008). TIMSS 2007 International Mathematics Report. Chestnut Hill, MA: International Study Center.

Martínková, P., Goldhaber, D. \& Erosheva, E. (2018). Disparities in ratings of internal and external applicants: A case for model-based inter-rater reliability. PLOS ONE, 13(10), e0203002. https://doi.org/10.1371/journal.pone.0203002

MEN. (2008). Podstawa programowa kszta tcenia ogólnego dla gimnazjów i szkól ponadgimnazjalnych, których ukończenie umożliwia uzyskanie świadectwa dojrzałości po zdaniu egzaminu maturalnego. Warszawa: Ministerstwo Edukacji Narodowej. Available from http://www.dbg.vdg.pl/attachments/article/10/rozporzadzenie_20081223_zal_4.pdf [retrieved November 2018]

MER. (2018a). Ministry of Education and Research (Estonia). Available from https://www.hm.ee/en [retrieved November 2018]

MER. (2018b). National curriculum for basic schools: Appendix 3. Available from https://www.hm.ee/en/national-curricula-2014 [retrieved November 2018]

MESS. (2018). Ministry of Education, Science and Sport (Slovenia). Available from http://www.mizs.gov.si/en/ [retrieved October 2018]

MNE. (2018). Ministry of National Education (Poland). Available from http://en.men.gov.pl/ [retrieved October 2018]

MIZঙ̆. (2018a). Osnovo šolstvo. Available from http://www.mizs.gov.si/si/ delovna_podrocja/direktorat_za_predsolsko_vzgojo_in_osnovno_solstvo/osnovno_solstvo/ [retrieved November 2018]

MIZS̆. (2018b). Matematika - Učni načrt. Available from http://www.mizs.gov.si/si/ delovna_podrocja/direktorat_za_predsolsko_vzgojo_in_osnovno_solstvo/osnovno_solstvo/ ucni_nacrti/ [retrieved November 2018]

MŠ. (1987). Učební osnovy základní školy: Matematika 5.-8. ročník.

Matematicko-fyzikální praktika. Cvičení z matematiky. Praha: SPN.

MŠMT. (1991). Učebni osnovy základni školy: Matematika 5.-8. ročník, Informatika 7.-8. ročník, Rýsování a technické kresleni 7.-8. ročník. Praha: Fortuna.

MŠMT. (1996). Matematika. Učební osnovy pro 1. až 9. ročnik: Vzdělávací program Základni škola. Praha: Fortuna.

MŠMT. (2001). National programme for the Development of Education. White paper. Praha: UIV. Available from http://www.msmt.cz/dokumenty/bila-kniha-narodniprogram-rozvoje-vzdelavani-v-ceske-republice-formuje-vladni-strategii-v-oblastivzdelavani-strategie-odrazi-celospolecenske-zajmy-a-dava-konkretni-podnety-k-praci-skol

MŠMT. (2007). Framework Educational Programme for Basic Education. Available from http://www.msmt.cz/file/9481_1_1

MŠMT. (2011). Doporučené učební osnovy předměti CJJL, AJ a M pro základní školu. Available from http://www.vuppraha.rvp.cz/wp-content/uploads/2011/03/

Doporucene-ucebni-osnovy-predmetu-CJL-AJ-a-M-pro-zakladni-skolu.pdf

MŠMT. (2017). Rámcový vzdělávací program pro základní vzdělávání. Praha: MŠMT. Available from http://www.msmt.cz/file/43792/

MŠMT. (2018a). Harmonogram. Available from

http://www.msmt.cz/vzdelavani/skolstvi-v-cr/skolskareforma/harmonogram [retrieved November 2018] 
MŠMT. (2018b). Ministry of Education, Youth and Sports (Czech Republic). Available from http://www.msmt.cz/?lang=2 [retrieved October 2018]

Mullis, I. V.S., et al. (Eds.). (2001). TIMSS assessment frameworks and specifications 2003. Chestnut Hill, MA: International Study Center.

Mullis, I. V.S., et al. (Eds.). (2012). TIMSS 2011 international results in mathematics. Chestnut Hill, MA: International Study Center.

Mullis, I. V.S., et al. (Eds). (2016). TIMSS 2015 international results in mathematics. Chestnut Hill, MA: International Study Center.

Mullis, I. V. S., Martin, M. O. \& Loveless, T. (2016). 20 Years of TIMSS: International trends in mathematics and science achievement, curriculum, and instruction. Chestnut Hill, MA: International Study Center.

OECD. (2004). Learning for tomorrow's world. First results from PISA 2003. Paris: OECD Publishing.

OECD. (2013a). PISA 2012 assessment and analytical framework: Mathematics, reading, science, problem solving and financial literacy. Paris: OECD Publishing.

OECD. (2013b). PISA 2012 results: What makes schools successful (Volume IV): Resources, policies and practices. Paris: OECD Publishing.

OECD. (2014a). PISA 2012 results in focus. What 15-year-olds know and what they can do with what they know. Paris: OECD Publishing.

OECD. (2014b). PISA 2012 results: What students know and can do. Paris: OECD Publishing.

OECD. (2014c). Does homework perpetuate inequities in education? PISA in Focus, No. 46, 1-4. https://doi.org/10.1787/5jxrhqhtx2xt-en

OECD. (2016). Education policy outlook: Estonia. Paris: OECD Publishing.

OECD. (2018). PISA 2015. Results in focus. Paris: OECD Publishing.

Pešková, K., Spurná, M. \& Knecht, P. (2017). Teoretický model pro výzkum vnímání kurikulárních změn učiteli Zঙ̆. Orbis Scholae, 11(2), 99-124.

https://doi.org/10.14712/23363177.2018.271

Průcha, J. (1999). Vzdělávání a školství ve světě. Praha: Portál.

Průcha, J. (2012). Srovnávací pedagogika. Praha: Portál.

Rivkin, S. G. \& Schiman, J. C. (2013). Instruction time, classroom quality, and academic achievement. The Economic Journal, 125(588), F425-F448.

https://doi.org/10.3386/w19464

Roter, A. (2003). Reforma szkolnictwa w Polsce a priorytety Unii Europejskiej. In J. Prokop (Ed.), K otázkám srovnávací pedagogiky (39-43). Praha: Karolinum.

Santiago, P., et al. (2016). OECD reviews of school resources: Estonia 2016. Paris: OECD Publishing.

Slavík, J. \& Janík, T. (2012). Kvalita výuky: obsahově zaměřený přístup ke studiu procesů vyučování a učení. Pedagogika, 62(3), 262-286.

Straková, J. (2007). Kurikulární reforma z pohledu šetření Kalibro. Pedagogika, 57(1), $21-36$. 
Straková, J. (2015). Mezinárodní výzkumy vědomostí a dovedností: historie a současnost. In D. Greger (Ed.), Srovnávací pedagogika: Proměny a výzvy (83-99). Praha: Univerzita Karlova v Praze, Pedagogická fakulta.

UNESCO. (2018). International standard classification of education. Available from http://uis.unesco.org/ [retrieved October 2018]

Walterová, E. (1994). Kurikulum. Proměny a trendy v mezinárodní perspektivě. Brno: Masarykova univerzita v Brně.

Walterová, E. (2006). Srovnávací pedagogika. Vývoj a proměny v globálním kontextu. Praha: Univerzita Karlova, Pedagogická fakulta.

Wiseman, A. W. (2010). The impact of international achievement studies on national education policymaking. Bingley: Emerald Group Publishing Limited.

Wiśniewski, J. (2007). Secondary educatione in Poland: 18 years of changes. Conference paper for fourth ECA education conference, Tirana, 24-26 October 2007. Available from http://siteresources.worldbank.org/EXTECAREGTOPEDUCATION/Resources/ 444607-1192636551820/Secondary_education_in_Poland_jwi_4r.pdf

Woessmann, L. (2016). The importance of school system: Evidence from international difference in student achievement. Journal of Economic Perspectives, 30(3), 3-32. https://doi.org/10.1257/jep.30.3.3

Vlasta MoRAVCOVÁ, morava@karlin.mff.cuni.cz PETRA SuRYNKovÁ, surynkova@karlin.mff.cuni.cz JANA HromadovÁ, jole@karlin.mff.cuni.cz Charles University, Faculty of Mathematics and Physics Department of Mathematical Education

Sokolovská 83, 18675 Prague 8, Czech Republic 


\section{APPENDIX}

Tab. A1: The learning outcomes and content in mathematics with the emphasis on geometry in the Czech Republic

\begin{tabular}{|c|c|c|}
\hline & Learning outcomes & Learning content \\
\hline \multicolumn{3}{|l|}{$\overline{\text { Czech Republic }}$} \\
\hline $\begin{array}{l}\text { Two- and Three- } \\
\text { dimensional } \\
\text { Geometry }\end{array}$ & 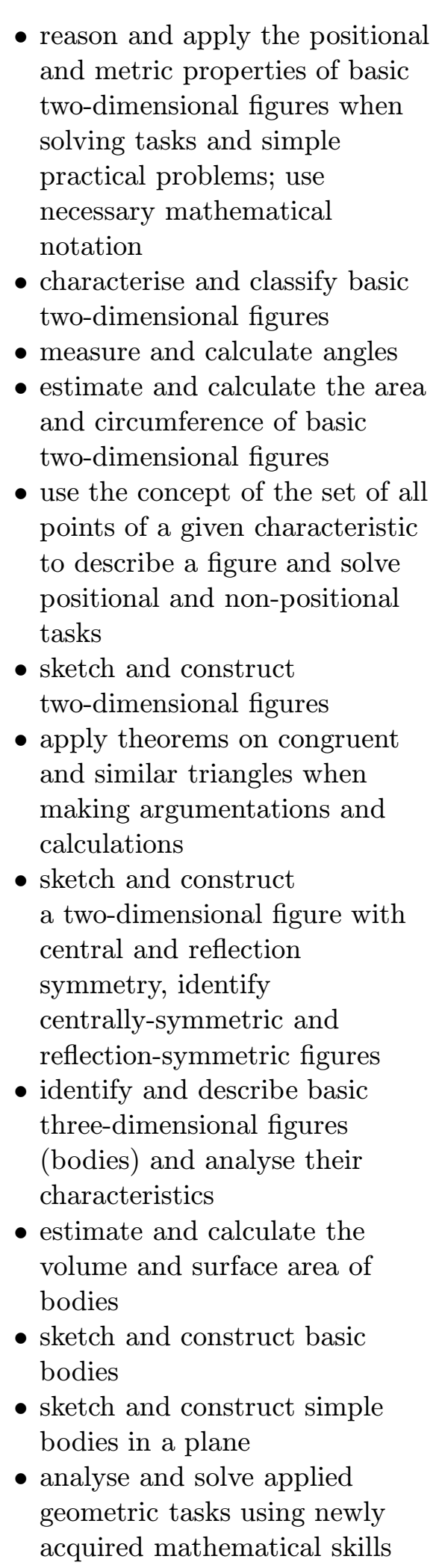 & $\begin{array}{l}\text { - two-dimensional figures - } \\
\text { lines, rays, line segments, disks, } \\
\text { circles, angles, triangles, } \\
\text { quadrilaterals (trapeziums, } \\
\text { parallelograms), regular } \\
\text { polygons, relative position of } \\
\text { two lines on a plane (types of } \\
\text { angles), congruence and } \\
\text { similarity (theorems on } \\
\text { congruent and similar } \\
\text { triangles) } \\
\text { - characteristics of } \\
\text { two-dimensional } \\
\text { measurements - types of } \\
\text { angles, distance of a point from } \\
\text { a line, triangle inequality, } \\
\text { Pythagoras' theorem } \\
\text { - three-dimensional figures - } \\
\text { cuboids, cubes, right circular } \\
\text { cylinders, pyramids, right } \\
\text { circular cones, spheres, right } \\
\text { prisms } \\
\text { - construction tasks - } \\
\text { multiples of all points of } \\
\text { a given characteristic (segment } \\
\text { bisectors, angle bisectors, } \\
\text { Thales' circle), reflection } \\
\text { symmetry, central symmetry }\end{array}$ \\
\hline
\end{tabular}


Tab. A2: The learning outcomes and content in mathematics with the emphasis on geometry in Estonia

\begin{tabular}{|c|c|c|}
\hline & Learning outcomes & Learning content \\
\hline \multicolumn{3}{|l|}{ Estonia } \\
\hline Geometry & $\begin{array}{l}\text { - draw and construct (both by } \\
\text { hand and computer) plane } \\
\text { figures on the basis of given } \\
\text { elements } \\
\text { - calculate linear elements, } \\
\text { perimeter and area and volume } \\
\text { of figures } \\
\text { - know figures, the midline of } \\
\text { a triangle and trapezium, the } \\
\text { median of a triangle, the } \\
\text { circumscribed and inscribed } \\
\text { circles of a triangle and the } \\
\text { central angle and peripheral } \\
\text { angles of triangle } \\
\text { - describe properties of figures } \\
\text { and classify figures according } \\
\text { to common properties } \\
\text { - identify the 'theorem', } \\
\text { 'postulate', 'assertion' and } \\
\text { 'proof', explain train of } \\
\text { thought of proving certain } \\
\text { theorems } \\
\text { - solve open-end problems with } \\
\text { geometrical content } \\
\text { - find the linear elements of } \\
\text { a right-angled triangle } \\
\text { - use similarity between triangles } \\
\text { and polygons when solving } \\
\text { open-end problems } \\
\text { - use technological tools in } \\
\text { discovering regularities and } \\
\text { formulating hypotheses }\end{array}$ & $\begin{array}{l}\text { - definition, theorem, } \\
\text { assumption, assertion and } \\
\text { proof } \\
\text { - polygons (triangle, } \\
\text { parallelogram, trapezium and } \\
\text { regular polygon), perimeter } \\
\text { and area of polygons } \\
\text { - circle and circumference } \\
\text { - central angle } \\
\text { - peripheral angle, Thales' } \\
\text { theorem } \\
\text { - tangent of circumference } \\
\text { - inscribed and circumscribed } \\
\text { circles of triangle and regular } \\
\text { polygon } \\
\text { - criterion of parallel straight } \\
\text { lines } \\
\text { - midline of triangle and } \\
\text { trapezium } \\
\text { - median and centre of gravity of } \\
\text { a triangle } \\
\text { - similarity properties of } \\
\text { triangles } \\
\text { - similarity of polygons } \\
\text { - planning of areas } \\
\text { - Pythagoras' theorem } \\
\text { - trigonometric functions of } \\
\text { acute angles } \\
\text { - solid figures (vertical } \\
\text { parallelepiped, vertical prism, } \\
\text { pyramid, cylinder, cone and } \\
\text { sphere), their area and volume }\end{array}$ \\
\hline
\end{tabular}


Tab. A3: The learning outcomes and content in mathematics with the emphasis on geometry in Poland

\begin{tabular}{|c|c|c|}
\hline & Learning outcomes & Learning content \\
\hline \multicolumn{3}{|l|}{ Poland } \\
\hline $\begin{array}{l}\text { Two- } \\
\text { dimensional } \\
\text { Figures }\end{array}$ & 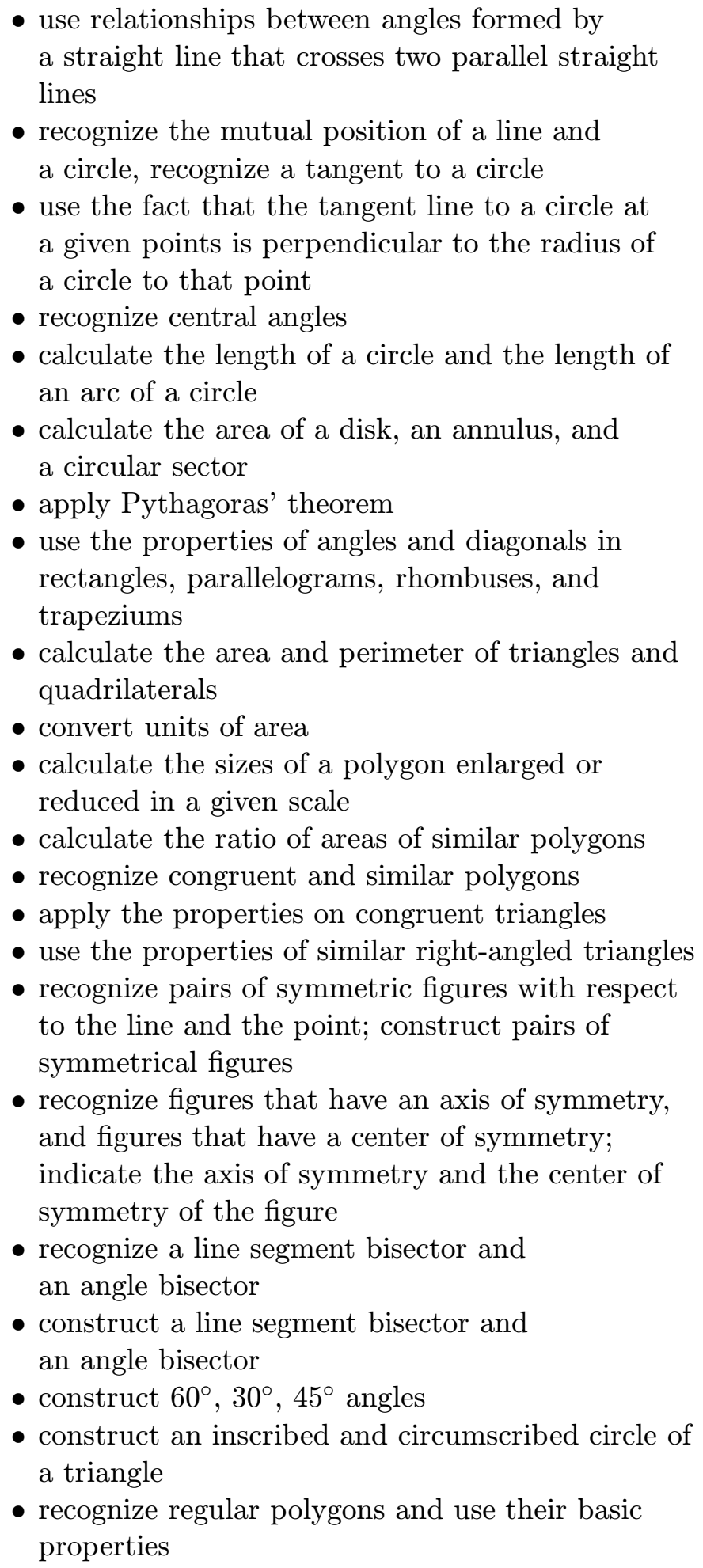 & $\begin{array}{l}\text { not specifically } \\
\text { defined }\end{array}$ \\
\hline$\overline{\text { Solids }}$ & $\begin{array}{l}\text { - } \text { recognize correctly regular prisms and pyramids } \\
\text { - calculate the surface area and volume of a right } \\
\text { prism, pyramid, cylinder, cone, sphere (also in } \\
\text { tasks with a practical context) } \\
\text { - convert volume units }\end{array}$ & $\begin{array}{l}\text { not specifically } \\
\text { defined }\end{array}$ \\
\hline
\end{tabular}


Tab. A4: The learning outcomes and content in mathematics with the emphasis on geometry in Slovenia

\begin{tabular}{|c|c|c|}
\hline & Learning outcomes & Learning content \\
\hline \multicolumn{3}{|l|}{$\overline{\text { Slovenia }}$} \\
\hline $\begin{array}{l}\text { Geometry and } \\
\text { Measurement }\end{array}$ & 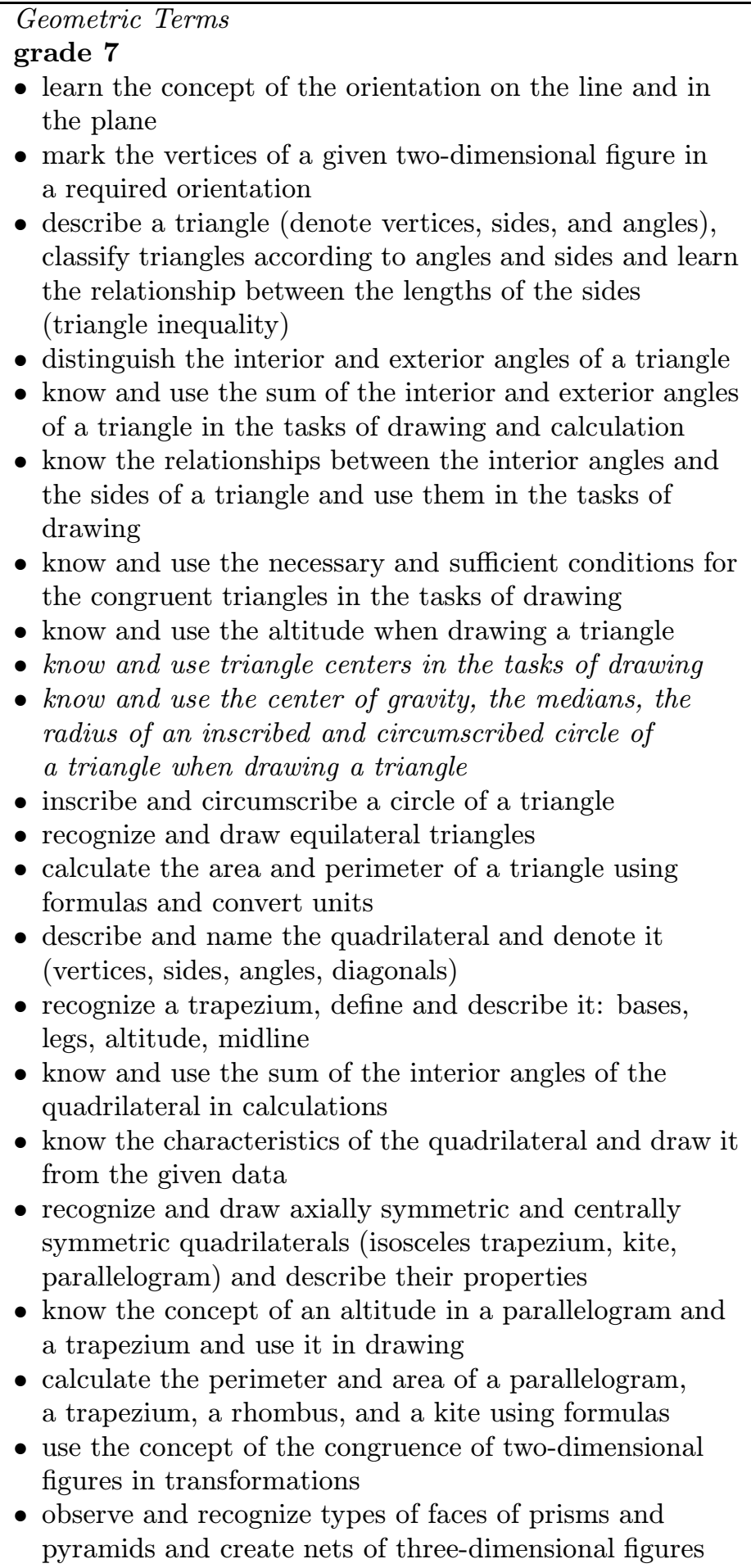 & $\begin{array}{l}\text { Geometric Terms } \\
\text { grade } 7 \\
\text { - } \text { orientation on } \\
\text { the line and in } \\
\text { the plane } \\
\text { - solids - adopting } \\
\text { the spatial } \\
\text { abilities } \\
\text { - triangle } \\
\text { - quadrilateral } \\
\text { - parallelogram } \\
\text { - rhombus } \\
\text { - trapezium } \\
\text { - kite } \\
\text { - the area and } \\
\text { perimeter of } \\
\text { two-dimensional } \\
\text { figures } \\
\text { - two-dimensional } \\
\text { figures on the } \\
\text { solids (the net of } \\
\text { solids) }\end{array}$ \\
\hline
\end{tabular}


Tab. A4: continue

\section{grade 8}

- describe the polygon and denote it (vertices, sides, angles, and diagonals)

- know the sum of the interior and exterior angles of a polygon

- adopt the concept of a regular polygon

- know and use the strategies for drawing polygons

- use the strategies for calculating the perimeter and area of polygons (for example using a formula, by measuring, by transforming to another two-dimensional figures)

- understand the concept of the number $\pi$

- calculate the circumference and area of the disk using formulas

- calculate the length of a circular arc and the area of a circular sector using formulas

- understand and use the length of the circular arc as the part of the length of the circle and the area of the circular sector as the part of the area of the disk

- solve the tasks with a circle (with or without calculators)

- know the properties of a right-angled triangle and name the sides

- know Pythagoras' theorem and apply it to calculate the lengths of sides in a right-angled triangle

- solve the tasks using Pythagoras' theorem in the plane (with or without calculators)

- know the concept of the cube and cuboid

- calculate the surface area and volume of the cube and cuboid (with or without calculators)

- apply Pythagoras' theorem in tasks with the cube and cuboid

- use the area and volume formulas for the cube and cuboid to calculate unknown variables 
grade 9

- define the relationships between points, lines, and grade 9 planes in the three-dimensional space (using models) and the relationship denote symbolically

- define and use the ratio of the line segments to calculate the unknown lengths

- partitioning a line segment in a given ratio

- recognize similar triangles and know the related terms: corresponding sides and congruent angles

- define and use the concept of similar triangles

- know and use Thales' theorem

- know the concept of the prism, cylinder, pyramid, and cone

- calculate the surface area and volume of the prism and cylinder (with or without calculators)

- understand and use the concept of mass, density and volume of the solid

- create models of solids and draw their nets (regular prisms and cylinders, regular pyramids and cones)

- calculate the lateral surface, surface area and volume of pyramids and cones (direct and indirect tasks)

- use formulas to calculate the surface area and volume of prisms, cylinders, pyramids, and cones and calculate the unknown variables

- apply Pythagoras' theorem in tasks with the solids

- adopt the concept of an axial cross section of the cone and solve the related tasks

- describe the sphere

- solve the tasks related to the surface area and volume of the sphere

- know the cylinder and cone as the solid of revolution

Transformations

- know transformations (reflection, translation, rotation) and their properties

- reflect a point, a line, a segment line, an angle, a two-dimensional figure across a given line or point

- describe the properties of reflection and write it symbolically

- adopt the concept of a line segment bisector and an angle bisector and solve the construction tasks

- use various strategies to construct an angle with a compass and a ruler

- recognize angles with the pair of parallel sides (alternate angles) and determine the relationship between their sizes

- find the vertical and adjacent angle to a given angle

- solve the tasks with a pair of angles

- form the formulas of rotation and reflection Transformations grade 7

- the properties of geometric transformations

- axial symmetry

- point reflection

- rotation

grade 8

- transformations of polygons

grade 9

- transformations in coordinate system 